\title{
STRATEGIJE SUOČAVANJA SA ANKSIOZNOŠĆU U SITUACIJI TESTIRANJA ENGLESKOG JEZIKA KOD STUDENATA VISOKOG I NISKOG SAMOPOŠTOVANJA
}

\section{AUTORI}

Marina Malobabić', Ivana Nešić ${ }^{2}$, Vesna Jokanović ${ }^{3}$

${ }^{1}$ Klinika za neurologiju, Klinički centar Niš

${ }^{2}$ Akademija strukovnih studija Južna Srbija, Odsek za poslovne studije Blace

${ }^{3}$ Beogradska akademija poslovnih i umetničkih strukovnih studija
KORESPONDENT

Marina Malobabić

Klinički centar Niš

Klinika za neurologiju

marinasudimac@gmail.com

\section{SAŽETAK}

Uvod: Veliki deo akademskog života predstavljaju različiti vidovi testiranja, koja sama po sebi predstavljaju izrazito stresne situacije za većinu studenata. Kada se situaciji testiranja doda anksioznost koju studenti doživljavaju, kao i njihovi nivoi samopoštovanja, postavlja se pitanje strategija koje studenti upotrebljavaju za suočavanje sa anksioznošću u tim situacijama.

Cilj rada: Sagledavanje jezičke anksioznosti, samopoštovanja i sociodemografskih varijabli kao prediktora aktivnog korišćenja strategija suočavanja sa ispitnom situacijom.

Materijal i metode rada: Istraživanje je obuhvatilo 338 studenata sa pet fakulteta/viših škola, prosečne starosti 21.82 +2.561, kojima su zadavani upitnici Rosenbergova skala samopoštovanja, Skala suočavanja sa ispitnom situacijom i Skala za merenje anksioznosti na časovima stranog jezika.

Rezultati: Subskala jezička anksioznost prilikom testiranja ima najveću obrnutu prediktivnu vrednost $($ beta=-0.43, $p<0.001)$ strategije suočavanja sa ispitnom situacijom, stariji ispitanici imaju manje izraženo suočavanje sa ispitnom (beta=-0.23, $\mathrm{p}<0.001$ ) i što je veći strah od negativne evaluacije (beta $=0.21, p<0.001$ ) to se ispitanici više suočavaju u ispitnoj situaciji.

Zaključak: Što je veća testovna anksioznost, studenti manje koriste strategije suočavanja, kao i da se stariji studenti suočavaju manje sa stresnim ispitnim situacijama, ali da kod njih prisutnost izraženijeg straha od neefikasnosti dovodi do većeg suočavanja. Takođe, što je jača negativna percepcija socijalne evaluacije, to će se ispitanici više suočavati sa ispitnom situacijom uz pomoć različitih strategija.

Ključne reči: Jezička anksioznost, Strah od negativne evaluacije, Horwitz, samopoštovanje, Strategije suočavanja

\section{ENGLISH}

\section{SUMMARY}

Introduction: Different types of tests present a great part of the academic life, and the tests themselves are extremely stressful situations for most students. The question of strategies used for coping with anxiety in testing situations is raised by the anxiety experienced by students and the levels of their self-esteem during tests.

Aim of the paper: The aim of the paper is to take into consideration language anxiety, self-esteem and social and demographic variables as predictors of active use of strategies for coping with the testing situation.

Material and methodology: This research included 338 students from five faculties/colleges, with an average age of $21.82 \pm 2.561$, who were administered the following scales: Rosenberg's Self-esteem Scale, the Coping with the Testing Situation Scale and Foreign Language Classroom Anxiety Scale.

Results: The Subscale for Language Anxiety during Testing has the highest reversed predictive value (beta $=-0.43, p<0.001$ ) of coping strategies for the testing situation; older respondents have less expressed ability of coping with the testing (beta=$0.23, p<0.001$ ), and the higher the level of fear from negative evaluation (beta $=0.21, p<0.001$ ), the more the respondents are coping with the testing situation.

Conclusion: The higher the testing anxiety, the less will the students use coping strategies, and the older students cope less with stressful testing situations, but the greater the presence of a more expressed fear of inefficiency, the more will the respondents cope with the testing situation through various strategies.

Key words: Language anxiety, Fear of negative evaluation, Horwitz, Self-esteem, Coping strategies 


\section{UVOD}

Samopoštovanje kao komponenta samo-koncepta predstavlja skup misli i osećanja pojedinca o sopstvenoj vrednosti i značaju. Drugim rečima, samopoštovanje se odnosi na pozitivne ili negativne stavove koje pojedinac ima prema samom sebi $[1 ; 2]$. Savremeni teoretičari posmatraju visoko samopoštovanje kao opšte osećanje da se sami sebi dopadamo, da sebe vrednujemo, poštujemo i prihvatamo [3,1]. Samopoštovanje shvaćeno na ovakav način može ojačati samopoštovanje sa emocijama o sebi kao celini, a ne sa procenom nečijih različitih osobina ili kvaliteta.

Ovako definisano samopoštovanje odnosi se na globalno samopoštovanje koje ne treba izjednačavati sa specifičnim samopoštovanjem. Naime, samopoštovanje sagledavamo u odnosu na to da li je relevantno za određeno ponašanje (specifično samopoštovanje) ili je relevantno za uopšteno psihološko stanje (globalno samopoštovanje)[4:144]. Takođe, specifično samopoštovanje je bolji prediktor specifičnog ponašanja, što je za naše istraživanje značajnije budući da se bavi samopoštovanjem u odnosu na specifično ponašanje, odnosno situaciju - testiranje engleskog jezika.

Anksioznost se može posmatrati kao osobina koja je suprotna visokom samopouzdanju, odnosno volji ili želji da se rizikuje [5:93]. Problem anksioznosti predstavlja ozbiljnu prepreku u postizanju jezičke fluentnosti [6:126]. Dakle, anksioznost predstavlja prepreku za razvoj komunikativnih kompetencija u učenju stranog jezika koje su uslovljenje konverzacijskom interakcijom. Jezička anksioznost se odnosi na specifičnu situaciju u kojoj se javlja. U našem istraživanju, specifična situacija se odnosi na učenje stranog jezika na času, a anksioznost koja se tada javlja je jezička anksioznost [7].

Horwitz i saradnici [6:127] opisuju tri međusobno povezane kategorije jezičke anksioznosti: 1) strah od komunikacije ili komunikacijska anskioznost (npr. usmena komunikacija, trema od javnog nastupa). Komunikacijska anksioznost potiče iz učenikovog osećanja da će imati poteškoće da razume svoje sagovornike ili da će oni njega teško razumeti. Isti autori smatraju da je interakcija veoma bitna za učenje stranog jezika jer podrazumeva ne samo sušto učenje već i usmenu reprodukciju jezika. Usmena komunikacija uključuje slušanje i govor. Govor na stranom jeziku izaziva anksioznost kod većine učenika, a posebno kod usmenog izražavanja pred vršnjacima u odeljenju [8]; 2) Anksioznost prilikom testiranja izazvana je strahom od neuspeha, a učenje stranog jezika mora podrazumevati i neki vid ocenjivanja. Budući da se anksioznost prilikom testiranja uglavnom povezuje sa niskom performansom na ispitima i nižim ukupnim ocenama $[9 ; 10]$, strategije za rešavanje tog problema od velikog značaja za nastavnike i istraživače [11]; 3) Strah od negativnog ocenjivanja razlikuje se od anksioznosti prilikom testiranja jer se ne odnosi isključivo na situacije u kojima se učenici testiraju.

Suočavanje se definiše kao konstantno menjanje kognitivnih i bihevioralnih napora kako bi se savladali unutrašnji i/ili spoljašnji zahtevi koje pojedinac procenjuje kao prevelike. Suočavanje je usko povezano sa kontekstom i od njega zavisi pa je stoga značajan uticaj procene specifičnih zahteva situacije i sposobnost pojedinca da savlada te zahteve i promene do kojih dolazi [12,13].

Stresne situacije vezane za akademski uspeh i interpersonalne odnose mogu se svesti pod kategoriju svakodnevnih uznemiravajućih događaja (eng. daily hassels). Kumulativan efekat takvih događaja povezuje se sa negativnim posledicama po zdravlje i psihosocijalno funkcionisanje ispitanika [14]. Usmeravanje na zadatak smatra se prilagodljivijom strategijom emocionalne regulacije $u$ ispitnim situacijama jer pomaže učenicima da zadrže fokus na samim ispitnim zadacima što doprinosi boljoj performansi [15]. Suprotno tome, strategije emocionalne regulacije koje se usmeravaju na doživljene emocije $u$ ispitnim situacijama imaju manji efekat jer razmišljanje o sopstvenim emocionalnim iskustvima i uzrocima performance udaljavaju učenika od samog zadatka polaganja ispita.

S obzirom na to da je ispitna situacija sama po sebi stresna, istraživanje načina suočavanja sa njom je interesantna. Budući da različiti vidovi ocenjivanja igraju značajnu ulogu u određivanju profesionalne karijere, adaptivno suočavanje sa takvim situacijama postaje ključno za akademsko postignuće [16].

\section{MATERIJAL I METODE}

\section{Učesnici u istraživanju}

Istraživanje je sprovedeno među studentima na Visokoj školi elektrotehnike i računarstva strukovnih studija Beograd, Visokoj građevinsko-geodetskoj školi Beograd, Beogradskoj poslovnoj školi - Visoka škola strukovnih studija, Visokoj poslovnoj školi strukovnih studija Blace. Svi ispitanici su pohađali predmet Poslovni engleski jezik. Uzorak čini 338 ispitanika, od kojih je 155 muškog pola $(49,9 \%)$, dok je 183 bilo ženskog pola $(54,1 \%)$. Starost ispitanika se kretala od 18 do 29 godina (prosečna starost 21.82 \pm 2.561 ). Uzorak je prikupljan u periodu od 6 meseci, od septembra 2019. do februara 2020. godine.

\section{Instrumenti}

Globalno samopoštovanje operacionalizovano je preko upitnika The Rosenberg Self-Esteem Scale RSES [1]. Upitnik se sastoji od 10 stavki, izjava koje se odnose na samopoštovanje i samoprihvatanje na petostepenoj skali Likertovog tipa, od 1 (u potpunosti se ne slažem) do 5 (u potpunosi se slažem) [2]. Stavke se odnose na globalnu samoprocenu (koliko ispitanika smatra sebe vrednim), gde od njih 5 ima pozitivan smer, a 5 negativan. Pouzdanost Skale samopoštovanja (Self-esteem Scale) u našem uzorku iznosila je .832.

Drugi korišćeni upitnik je Skala suočavanja sa ispitnom situacijom autorke Izabele Sorić [16]. Skala sadrži 29 tvrdnji za koje ispitanici na skali Likertovog tipa procenjuju u kojoj se meri opisan način suočavanja odnosi na njih, pri čemu 1 označava uopšte se ne odnosi, a 5 u potpunosti se odnosi. Skala se sastoji od četiri subskale: suočavanje usmereno na emocije, suočavanje usmereno na problem, suočavanje traženjem pomoći i maštanje/distrakcija [17]. Na našem uzorku dobijeni su zadovoljavajući koeficijenti unutrašnje konzistentnosti (Kronbahov alfa za suočavanje usmereno na emocije .722, suočavanje usmereno na problem .730 , suočavanje korišćenjem pomoći .747 i maštanje/distrakcija .714).

Skalu za merenje anksioznosti na časovima stranog jezika' osmislili su Horwitz i saradnici [6]. Skala sadrži ukupno 33 stavki i Likertovog je tipa - svaka stavka se ocenjuje vrednostima od 1-5. Vrednosti petostepene skale su: 1 - u potpunosti se slažem, 2 - uglavnom se slažem, 3 - neodlučan sam, 4 - uglavnom se ne slažem i 5 - uopšte se ne slažem.

Eng. „Foreign Language Classroom Anxiety Scale“ 
Skala sadrži dva tipa iskaza - pozitivne i negativne iskaze, te su one stavke sa negativnim iskazima kodirane kako bi više ukupne vrednosti ukazivale na visok nivo ankioznosti kod ispitanika. Utvrđena je vrednost pouzdanosti unutrašnje konzistentnosti za Skalu merenja anksioznosti na časovima stranog jezika gde je vrednost koeficijenta Kronbahov alfa= .875 što ukazuje na visoku pouzdanost cele skale. Vrednosti Kronbahove alfe subskala na našem uzorku su sledeći: za subskalu Komunikacijska ankioznost (ukoliko se stavke 32, 14 i 24 izbrišu) .741, za subskalu Testovna anksioznost .749 i za subskalu Strah od negativne evaluacije Kronbah alfa vrednost je iznosila .745.

\section{Tok istraživanja}

Istraživanje je sprovedeno u periodu od septembra 2019. do februara 2020. godine. Ceo postupak sa upoznavanjem ispitanika o cilju istraživanja, njihovoj ulozi i zadatku trajao je 5 minuta, bez uočenih problema. Prikupljanje podataka je sprovedeno grupno na predavanjima i vežbama u navedenim visokoškolskim ustanovama, uz prethodni pristanak direktora i predmetnih profesora. Istraživanje je bilo anonimno.

\section{Statistička analiza}

Korišćena je višestruka linearna regresija (stepwise method) kako bi proverili sposobnost modela da predvidi iznos kriterijumske varijable nakon što se ukloni uticaj više dodatnih promenljivih.

\section{REZULTATI}

\begin{tabular}{|c|c|c|c|c|}
\hline & 1 & 2 & 3 & 4 \\
\hline Jezička anksioznost tokom testiranja & $-.347^{\star \star * \star}$ & $-.072^{\star \star * *}$ & $-.414^{* \star *}$ & $-.430^{\star \star *}$ \\
\hline Godine starosti & & $-.287^{\star * *}$ & $-.216^{* \star *}$ & $-.230^{* * *}$ \\
\hline Strah od negativne evaluacije & & & $.204^{\star \star}$ & $.211^{* *}$ \\
\hline Prosečna ocena & & & & -.038 \\
\hline & & & & .082 \\
\hline Komunikacijska anksioznost & & & & .033 \\
\hline Samopoštovanje & & & & .004 \\
\hline R squared & .120 & .200 & .225 & .232 \\
\hline Adjusted R squared & .118 & 195 & .218 & .216 \\
\hline $\mathrm{N}$ & 338 & & & \\
\hline
\end{tabular}

Za ocenu mogućnosti 3 prediktora (jezička ankioznost prilikom testiranja, strah od negativne evaluacije i godine starosti) da predvide nivo suočavanja sa ispitnom situacijom (skala suočavanja sa ispitnom situacijom), upotrebljena je hijerarhijska višestruka regresija nakon što je uklonjen uticaj komunikacijske anksioznosti, prosečne ocene, samopoštovanja i pola. Preliminarnim analizama je dokazano da pretpostavke normalnosti, linearnosti, multikolinearnosti i homogenosti varijanse nisu bile narušene. U prvom koraku su unete promenljive komunikacijske anksioznosti, prosečne ocene, samopoštovanja i pola, što je objasnilo $7,6 \%$ varijanse suočavanja sa ispitnom situacijom. Nakon unošenja skala jezička ankioznost prilikom testiranja, strah od negativne evaluacije i godine starosti u drugom koraku, modelom kao celinom je objašnjeno $23,2 \%$ ukupne varijanse, $F(7,330)=$ $14,249 \mathrm{p}<0.001$. Merila jezička ankioznost prilikom testiranja, strah od negativne evaluacije i godine starosti su objasnili $15,6 \%$ varijanse u suočavanju, nakon što je uklonjen uticaj promenljive komunikacijske anksioznosti, prosečne ocene, samopoštovanja i pola; $r$ se promenilo $z a=0.16$, F se promenilo za $(3,330)=22,290, p<0.001$. U konačnom modelu, statistički su bila značajna samo 3 merila suočavanja, pri čemu je skala jezička anksioznost prilikom testiranja imala najveći beta koeficijent (beta $=-0.43, p<0.001$ ), zatim godine starosti (beta $=-0.23, p<0.001$ ) i na kraju strah od negativne evaluacije (beta=0.21, $p<0.001$ ). Vidimo da je koeficijent za merila jezičke anksioznosti prilikom testiranja i godine starosti negativan što govori da je regresija obrnuta, odnosno, da je što je izraženija testovna anksioznost, to je manje suočavanje sa ispitnom situacijom i što su ispitanici stariji to je suočavanje sa ispitnom situacijom manje.

\section{DISKUSIJA}

Sarid i saradnici [18] su uočili strategiju suočavanja koja je slična poricanju, a Rohrmann i saradnici [19] strategiju sličnu suzbijanju; ove strategije su povezane sa nižim fiziološkim odgovorom u toku ispitivanja. Blankstein i saradnici [20] su pronašli da je anksioznost prilikom testiranja bila povezana sa izbegavanjem i suočavanjem fokusiranim na emocijama među studentima, a da je izbegavanje negativno povezano sa uspehom na testu [21]. Naši rezultati su pokazali da se studenti koji imaju izraženiju jezičku anksioznost prilikom testiranja generalno manje suočavaju sa ispitnom situacijom uopšte za šta razlog možemo naći u Bandurinoj teoriji samoefikasnosti. Bandura [22,23] smatra da su verovanja o samoefikasnosti ključni faktor u sistemu ljudskih sposobnosti što bi značilo da ista osoba u različitim okolnostima, može imati loš, adekvatan ili izvrstan performans, u zavisnosti od verovanja o samoefikasnosti. Ova teorija predviđa da kada je percepcija lične efikasnosti visoka, pojedinac će se truditi da radi one zadatke koji unapređuju njegov skup veština, dok će se pojedinci sa niskom samoefikasnošću „držati po strani“. Takođe, oni koji potcjenjuju samoefikasnost, u startu će svoj potencijal za razvoj osuditi na neuspeh i posledično će imati anksioznost i sumnju u sebe koje će povećati mogućnost neuspeha [24]. S obzirom da je anksioznost negativna emocija $[25,26]$ čiji je subjektivni doživljaj teško ignorisati, razumljivo je da su studenti uopšte motivisani da koriste strategije kako bi regulisali njen intenzitet, pri čemu su usmereniji na procese povezane uz sam emocionalni doživljaj, a manje na rešavanje problema tokom ispitivanja. Studenti koji su smatrali da mogu da kontrolišu ispitnu situaciju, odnosno da se suočavaju sa ispitnom situacijom uopšte, koristili su adaptivne strategije suočavanja - emocionalna regulacija, odnosno, suočavanje usmereno na zadatak [27]. Studenti koji su imali percepciju negativne evaluacije svoje grupe koristili i suočavanje usmereno na emocije i suočavanje sa ispitnom situacijom usmereno na problem.

Kada je strah od negativnog ocenjivana u pitanju, do sada su kognitivne procene ostvarile najveći samostalni doprinos objašnjavajući najveći procenat varijanse tri kriterijumske varijable. Rezultati dosadašnjih istraživanja su u skladu s teorijskim pretpostavkama i rezultatima prema kojima kognitivne procene čine glavne i neposredne antecedente emocionalnih iskustava i potencijal za njihovu regulaciju [15]. Naime, osobe sklone pozitivnoj percepciji neke situacije, u situaciji kao što je polaganje ispita, istraju u postizanju svojih ciljeva i prilikom nailaska na prepreke, s njima suočavaju tako da nastoje da kognitivno restrukturišu sadržaj ispitnih zadataka (aktivan pristup prevazilaženja), trude se da pronađu relevantne informacije i naglase pozitivne strane, iako je na temelju rezultata ranijih istraživanja očekivano da će i pesimizam doprineti objašnjenju nekih od strategija emocionalne regulacije $[28,29]$. Ovakvi rezultati idu u prilog objašnjenju naših rezultata gde se će studenti koji percipiraju procenu svojih sposobnosti od strane drugih 
kao negativnu, pokazivati veće napore prilikom suočavanja sa ispitnom situacijom, kako ne bi došlo do ostvarenja proreknute budućnosti (tipa kognitivne distorzije koji se često javlja kod socijalne anksioznosti) [30]. Juretić [23] navodi da kada osoba proživljava anksioznost pre i tokom ispita, ona se ne plaši testa ili pada na ispitu, već je ono što joj izaziva tu neprijatnu emociju socijalna reperkusija lošeg performansa, odnosno, to kako će je drugi videti i proceniti ako ona „omane“. Za većinu su studenata najvažnija „publika” profesori, roditelji i kolege te je ispitna anksioznost ustvari socijalna anksioznost koja se javlja kada je osoba izložena tuđoj proceni i trudi se da prikaže sebe kao dobrog, motivisanog i inteligentnog studenta ali veruje da će je loš rezultata na ispitu diskreditovati [31]. Moguće objašnjenje ovakvih nalaza može se tražiti i u samoj prirodi testovne anksioznosti koja nije jedinstven fenomen: učenici ispoljavaju testovnu anksioznost različitog porekla koja dalje može da produkuje i raznovrsne odnose istog nivoa testovne anksioznosti različitih učenika sa drugim motivacionim komponentama i samim procesom učenja.

Što se tiče performansa na testu, neki autori smatraju da zavisi od naših verovanja o sopstvenoj efikasnosti, u širem smislu i karakterističnim za određenu situaciju, u užem smislu. Ta verovanja koja imamo o svojoj samoefikasnosti, određuju kako se osećamo, mislimo i motivišemo sebe da se ponašamo na određen način [23].

Naši rezultati potvrđuju rezultate dosadašnjih istraživanja koja su pokazala da se stariji manje suočavaju [32]. Istraživanje nije pokazalo značajne razlike s obzirom na pol iako su u nekim istraživanjima utvrđene samo za faktor suočavanja usmerenog na emocije, dok s obzirom na vrstu studija nema značajnih razlika u pojedinim faktorima. Istraživanje Kalebić-Maglica [13] potvrdilo je kako devojke u većoj meri koriste emocijama usmereno suočavanje, a mlađi adolescenti u većoj meri izbegavaju.

\section{ZAKLJUČAK}

$\mathrm{Na}$ osnovu sprovedenog istraživanja i analiziranih rezultata, dolazimo do nekoliko zaključa koji se mogu koristiti kao preporuka za dalja istraživanja jezičke anksioznosti, samopoštovanja i strategija suočavanja. Analiza rezultata je pokazala da što je veća testovna anksioznost, studenti manje koriste strategije suočavanja, kao i da se stariji studenti suočavaju manje sa stresnim ispitnim situacijama, ali da kod njih prisutnost izraženijeg straha od neefikasnosti dovodi do većeg suočavanja. Takođe, istraživanje je pokazalo da oni koji procenjuju evaluaciju sebe od strane drugih studenata $i$ profesora kao moguće negativnu, služe se strategijama suočavanja sa ispitnom situacijom. Buduća istraživanja mogu poslužiti identifikaciji uzroka stresa kod studenata. Sprovedeno istraživanje može poslužiti kao temelj za neka buduća istraživanja stresnih situacija studenata jer rezultati ukazuju da studenti generalno, imaju poteškoće prilikom suočavanja sa stresnim ispitnim situacijama, te je kod potrebno unaprediti adekvatne $\mathrm{i}$ adaptivne načine suočavanja sa ispitnom situacijom.

\section{LITERATURA}

1. Rosenberg, M. (1965). Society and the adolescent self-image. Princeton, NJ: Princeton University Press.

2. Martín-Albo, J., Núñez, J. L., Navarro, J. G., \& Grijalvo, F. (2007). The Rosenberg Self-Esteem Scale: translation and validation in university students. The Spanish journal of psychology, 10(2), 458-467.

3. Brown, J. D. (1993). Self-esteem and self-evaluation: Feeling is believing. In J. Suls (Ed.), Psychological perspectives on the self (Vol. 4, pp. 27-58). Hillsdale, NJ: Lawrence Erlbaum Associates, Inc.

4. Rosenberg, M., Schooler, C., Schoenbach, C., \& Rosenberg, F. (1995). Global self-esteem and specific self-esteem: Different concepts, different outcomes. American sociological review, 141-156.

5. Graham, S. (1997). Effective Language Learning: Positive Strategies for Advanced Level Language Learning Modern Languages in Practice. Multilingual Matters Ltd.

6. Horwitz, E. K., Horwitz, M. B. and Cope, J. (1986). Foreign language classroom anxiety. The Modern Language Journal, 70, 125-132.

7. Nešić, I, Spasić-Stojković, M. (2018). Insights from students' language learning diaries, U N. Stojkovic (Ed.), Positioning English for Specific Purposes in an English Language Teaching Context, Chapter 11: 135-154, Vernon Press.

8. Young, D. (1986). The relationship between anxiety and foreign language oral proficiency ratings. In E. K. Young (ed.), Language anxiety: From theory and research to classroom implications (57-63). Englewood Cliffs, NJ: Prentice-Hall.

9. Hembree, R. (1988). Correlates, causes, effects, and treatment of test anxiety. Review of Educational Research, 58, 47-77.

10. Sarason, I.G. \& Sarason, B.R (1990). Test anxiety. In H. Leitenberg (Ed.), Handbook of social and evaluational anxiety (pp. 475-495). New York Plenum.

11. Kondo, D. S. (1997). Strategies for coping with test anxiety. Anxiety, Stress, and coping, 10(2), 203-215.

12. Lazarus, R. S. i Folkman S. (1984). Stress, appraisal, and coping. New York: Springer Publishing Company

13. Kalebić-Maglica, B. (2007). Uloga izražavanja emocija i suočavanja sa stresom vezanim uz školu u percepciji raspoloženja i tjelesnih simptoma adolescenata. Psihologijske teme, 16(1), 1-26.

14. Compas, B. E., Connor-Smith, J. K., Saltzman, H., Harding Thomsen, A. i Wadsworth, M. E. (2001). Coping with stress during childhood and adolescence: Problems, progress, and potential theory and research. Psychological Bulletin, 127, 87. 127.

15. Burić, I., Sorić, I., \& Penezić, Z. (2011). Strategije emocionalne regulacije u ispitnim situacijama: Doprinosi osobina ličnosti, kognitivnih procjena i ispitnih emocija. Psihologijske teme, 20(2), 277-298. 
16. Sorić, I. (1994). Kauzalne atribucije i strategije suočavanjau školskoj situaciji ispitivanja znanja. Neobjavljeni magistarski rad. Zagreb: Odsjek za psihologiju Filozofskog fakulteta u Zagrebu.

17. Sorić, I (1998). Usporedba osnovnih postavki Weinoreve i Lazarusove teorije emocija u školskoj situaciji ispitivanja znanja. Neobjavljena doktorska disertacija. Zagreb: Odsjek za psihologiju Filozofskog fakulteta u Zagrebu.

18. Sarid, O., Anson, O., Yaari, A., \& Margalith, M. (2004). Coping styles and changes in humoural reaction during academic stress. Psychology, health \& medicine, 9(1), 85-98.

19. Rohrmann, S., Netter, P., Hennig, J., \& Hodapp, V. (2003). Repression-sensitization, gender, and discrepancies in psychobiological reactions to examination stress. Anxiety, Stress \& Coping, 16(3), 321-329.

20. Blankstein, K. R., Flett, G. L., \& Watson, M. S. (1992). Coping and academic problem-solving ability in test anxiety. Journal of clinical psychology, 48(1), 37-46.

21. Edwards, J. M., \& Trimble, K. (1992). Anxiety, coping and academic performance. Anxiety, stress and coping, 5(4), 337-350.

22. Bandura, A. (1977). Self-efficacy: Toward a unifying theory of behavioral change. Psychological Review 84, 191-215.

23. Juretić, J. (2008). Socijalna i ispitna anksioznost te percepcija samoefikasnosti kao prediktori ishoda ispitne situacije. Psihologijske teme, 17(1), 15-36.

24. Pintrich, P. i Schunk, D. (1996). Motivation in Education: Theory, Research \& Applications. Englewood Cliffs, NJ: PrenticeHall.

25. Pekrun, R. (2006). The control-value theory of achievement emotions: Assumptions, corollaries, and implications for educational research and practice. Educational Psychology Review, 18, 315-341.

26. Pekrun, R., Goetz, T., Titz, W. i Perry, R.P. (2002). Academic emotions in studets' selfregulated learning and achievement: A program of qualitative and quantitative research. Educational Psychologist, 37(2), 91-105.

27. Brković, A. D., Petrović-Bjekić, D., \& Zlatić, L. (1998). Students' motivation for teaching courses. Psihologija, 31(1-2), 115136

28. Carver, C. S., \& Scheier, M. F. (1999). Themes and issues in the self-regulation of behavior. Advances in social cognition, 12(1), 1.

29. Chang, E. C., \& Farrehi, A. S. (2001). Optimism/pessimism and information-processing styles: can their influences be distinguished in predicting psychological adjustment?. Personality and individual differences, 31(4), 555-562.

30. Leahy, R. L. (2003). Cognitive therapy techniques: A practitioner's guide. New York:Guilford Publications.

31. Leary, M.R. i Kowalski, R.M. (1995). Social Anxiety. New York: The Guilford Press.

32. Šimić, K. (2017). Suočavanje studenata sa stresnim ispitnim situacijama. Acta ladertina, 14(2), 0-0. 